\title{
Stem Cells and Renal Regeneration
}

\author{
C. Roufosse H.T. Cook \\ Department of Histopathology, Imperial College Healthcare NHS Trust, Hammersmith Hospital, London, UK
}

\section{Key Words}

Bone marrow - Bone marrow-derived stem cells •

Embryonic stem cells • Fibrosis - Native renal stem cells •

Renal regeneration $\cdot$ Stem cells

\begin{abstract}
The role of embryonal or adult stem cells, in particular bone marrow (BM)-derived stem cells, in regenerating the kidney after injury has been the subject of intensive investigation. $\mathrm{BM}$-derived stem cells have been shown to give rise to small numbers of most renal cell types, including tubular cells, mesangial cells, podocytes, vascular cells and interstitial cells. However, the role this infrequent display of BM cell plasticity plays in organ regeneration is less certain. Injections of BMderived cells do improve renal function in many animal models of renal disease. Current opinion attributes this renoprotective effect mainly to paracrine factors supporting regeneration by local renal cells and to immunomodulatory effects, rather than to transdifferentiation of BM cells into renal cells. Several groups have identified native renal stem cell populations, although their role in renal regeneration has not yet been well defined.
\end{abstract}

Copyright $\odot 2008$ S. Karger AG, Basel

\section{Introduction}

In the 20th century, a lease of life was given to patients with renal failure through the development of kidney transplantation. This technique has proved successful, but is marred by limited organ availability and graft survival, largely due to immune rejection. More recently, hope has been placed in the development of stem cellbased therapies, in which the function of the failing organ is restored by injected multipotent cells. Possible sources for these cells include organ-specific local stem cells within the kidney, and circulating multipotent cells, such as bone marrow (BM)-derived stem cells. Using the patient's own stem cells to repair kidney damage could circumvent the problems of immune rejection and organ availability.

Kidneys are capable of a degree of regeneration, which varies among species. Some bony and cartilaginous fish continue to form new nephrons during adult life. Adult mammals have never been observed to form new nephrons but, to a certain extent, tubules and glomeruli may recover structure and function after limited injury such as acute tubular necrosis. Severe or prolonged injury results in replacement of functional parenchyma by scar tissue, i.e. fibrosis, which correlates clinically with the development of renal failure.

An effective treatment of renal disease would aim to encourage renal cell regeneration, or replace damaged renal cells, and discourage fibrosis, so we must first understand how renal cells regenerate. Experimental models have shown several possibilities, which are not mutually exclusive. Most commonly cited origins for renal parenchymal cells are: (1) the re-entry into cell cycle of differentiated cells; (2) direct transdifferentiation of one cell type into another (for example of tubular cells into interstitial cells or vice versa), and (3) differentiation from a stem cell population from the kidney or the BM.

Our review will cover the evidence for involvement of embryonic stem (ES) cells, native renal stem cells and BM-derived stem cells in kidney regeneration.

\section{KARGER \\ Fax +41613061234 \\ E-Mail karger@karger.ch}

www.karger.com

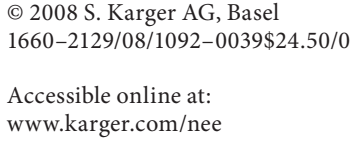

Dr. Candice Roufosse

Department of Histopathology, Imperial College Healthcare NHS Trust

Hammersmith Hospital, Du Cane Road, London W12 0HS (UK)

Tel. +44 208383 3280, Fax +44208383 1958

E-Mail Candice.Roufosse@imperial.nhs.uk 


\section{Embryonic Stem Cells}

The use of human embryonic ES cells for the treatment of organ dysfunction is associated with legal and ethical issues which society as a whole has yet to decide on. In the meantime, fundamental research aiming to prove that ES cells can be directed into forming renal progenitor cells, and eventually differentiated renal cells, is underway.

ES cells are pluripotent cells derived from the inner cell mass of blastocysts, and are in theory able to give rise to all the cell types of the body. ES cell lines have been derived from mice, non-human primates and humans [1]. In vivo injection of ES cells can give rise to teratomas, which are tumours containing cells of all three lineages (ectoderm, endoderm and mesoderm). This tumorigenesis may limit the clinical use of ES cells to treat organ dysfunction. Nevertheless, in murine ES cell-derived teratomas in vivo, renal primordial structures can be detected histochemically, and genes involved in metanephrogenesis are expressed [2]. This same potential was noted when ES cells were injected into embryonic mouse kidneys in vitro, and gave rise to ES cell-derived tubules, in this case without forming teratomas [3]. In vitro, transfection of murine ES cells with renal developmental gene Wnt4, as well as the addition of hepatocyte growth factor and activin-A, both promote the formation of renal tubule-like structures, with expression of tubular marker aquaporin-2 [4]. The Wnt4-transfected cells were transplanted into mouse renal cortex, where they also expressed aquaporin-2 and formed tubular structures. Similarly, murine ES cells primed in vitro with retinoic acid, activin-A and BMP-7 [5], activin-A alone [6], or BMP-4 [7], differentiate into cells expressing markers of the intermediate mesoderm, early kidney development and/or renal tubule-specific markers [5-7]. After injection of these primed murine ES cells into embryonic kidney cultures, ES cells were incorporated into developing renal tubules, without cell fusion [5], or into the nephrogenic zone [6]. The primed cells were enriched for renal progenitor cells by FACS and injected in vivo into the kidneys of newborn mice, where they were integrated as proximal tubular cells, without teratoma formation [6].

There are very few studies using human ES cells. In one study, human ES cells differentiated in vitro into WT1- and renin-expressing cells following treatment with a combination of specific growth factors [8].

In summary, research into the role for ES cells in renal regeneration is still in its infancy.

\section{Native Renal Stem Cells and Renal Regeneration}

In the embryo, most types of renal parenchymal cells are derived from metanephric mesenchymal cells, which are multipotent and are in addition self-renewing, making them attractive candidates as the stem cells of the embryonic kidney.

In animal models, embryonal metanephroi transplanted into the abdominal cavity of adult animals are colonized by host vasculature, undergo nephrogenesis and produce urine, even if the operation is carried out across species barriers, and with a surprising lack of rejection [reviewed in 9]. Human and porcine embryonic kidney progenitor cells have been isolated and, when injected into mice, can lead to the formation of miniature kidneys producing urine [10], or protect against acute renal failure [11]. There are however ethical issues to deal with.

Do such cells persist in the adult kidney? In adult mammals, a range of methods have been used to identify potential multipotent precursor cells, including label retention in slow cycling cells, identification of a side population, and expression of stem cell markers such as CD133. This has led to the identification of several candidate renal stem cells, which, depending on the study, are located amongst the tubular cell population [12-16], in the Bowman's capsule [17], in the papillary region $[18,19]$ or in the cortical interstitium [20]. Of note, other studies have not confirmed the presence of a large pool of precursor cells amongst the tubular population and instead argue that regeneration occurs through proliferation of differentiated tubular cells [21]. Some of the candidate renal stem cells have been shown to enhance recovery after tubular injury, possibly by integration in the tubular epithelium $[17,20]$.

This wealth of potential precursor populations is confusing. Their relationship with one another and their role in renal regeneration remains to be clarified.

\section{Bone Marrow-Derived Stem Cells and Renal Regeneration}

BM stem cells would be an ideal source of multipotent cells: they are easy to harvest and are in theory an unlimited source of expandable autologous cells. They display an unexpected plasticity which has been the subject of extensive research over the last few years. The plasticity has been observed both for the haematopoietic stem cell (HSC), which gives rise to all differentiated blood cell 
types, as well as for the BM mesenchymal stem cells (MSCs), which provide stromal support for HSC in the $\mathrm{BM}$, and also give rise to various mesenchymal tissues, such as bone, cartilage and fat.

There are important discrepancies in the literature addressing the role of BM cells in renal regeneration. These are partly explained by the methods involved in this research.

The technique most commonly used to study BM cell plasticity is BM transplantation. The host BM is replaced by donor BM, and after BM chimerism is established, donor cells are tracked down in the kidney. The donor BM cells are distinguished from host cells by virtue of their chromosome content (male Y chromosome-positive cells in a female host), the expression of a reporter molecule ( $\beta$-galactosidase, luciferase, enhanced green fluorescent protein), or the performance of a function (re-establishment of a function in a knockout mouse model). The type of host cell that the BM-derived cell has given rise to (tubular, mesangial, etc.) is ascertained most often using immunohistochemistry.

Discrepancies between studies are attributable to several factors: (1) observations in different species (mouse, rat, human); (2) use of different models of renal damage (ischaemia/reperfusion, toxic, immunological); (3) different protocols for BM transplantation (irradiation doses, quantity of cells injected); (4) injection of different subgroups of BM cells (whole BM, HSC, MSC); (5) sensitivity and specificity of the detection method for BM cell origin (in situ hybridization for the $\mathrm{Y}$ chromosome, detection of reporter molecules, functional assays), and (6) sensitivity and specificity of the detection method of the renal cell type (immunohistochemistry for specific cell types such as tubular cell, mesangial cells, etc.).

It is useful to bear in mind these technical variations when analysing results reported in the literature.

Renal failure can be the result of an initial insult directed against the tubular epithelium, the glomerular cells or the vascular compartment. In the search for remedies for these varied renal diseases, studies have therefore addressed potential $\mathrm{BM}$ origin for various renal cell types.

\section{Tubular Epithelium}

The $\mathrm{BM}$ origin of tubular epithelial cells has been one of the hottest debates in the last few years. Although initial studies suggested a high contribution of BM to tubular regeneration, the current view is that only a small proportion of tubular cells are BM-derived (a few percent), and there is disagreement over whether MSCs, HSCs or both are contributing [discussed in 22, 23]. The current consensus view is that the predominant source of tubular regeneration is through the proliferation of differentiated tubular cells $[24,25]$. A few authors have not found any $\mathrm{BM}$ cells engrafted in tubules, and propose that positive observations of BM-derived tubular cells are the result of artefact [26, also reviewed in 22, 23, 27].

As discussed above, there may also be a progenitor slow-cycling cell population contributing to tubular repair $[13,16]$.

Does this abolish the hope of harnessing the regenerative power of BM-derived cells? Not necessarily.

Firstly, a recent study has illustrated that under certain circumstances, BM engraftment in tubules can be dramatically increased. Held et al. [28] made use of a transgenic fumarylacetoacetate (FAH)-/- mouse, in which discontinuation of the rescue drug NTBC leads to acute tubular necrosis. After transplanting BM from wild-type mice into FAH-/- mice, a few BM-derived tubular cells were noted. In a subset of the FAH-/- mice, there was, in addition, loss of heterozygosity (LOH) in the liver for homogentistic acid hydrogenase, which induces a more severe, ongoing form of acute tubular necrosis. In FAH-/animals with additional hepatic $\mathrm{LOH}$, up to $50 \%$ of tubular cells were BM-derived cells. Engraftment of these wild-type BM-derived cells led to morphological resolution of ATN and to disappearance of the aminoaciduria present in control mice. In this model, the BM cells had a strong survival advantage over native tubular cells, due to their ability to metabolise toxic products. It is possible that this strong positive selective pressure is necessary for regeneration to occur through wild-type BM cells. Interestingly, most of the BM-derived tubular cells were derived from cell fusion between BM cells and tubular cells. This is supported by a study by Li et al. [29] in which fusion of BM cells to tubular cells accounted for part of BMderived tubular cells after ischaemia/reperfusion (I/R) injury, but not all. In this model without selective pressure, the percentage of BM-derived tubular cells was low $(1.8 \%)$.

Secondly, although there is disagreement concerning the underlying mechanism, injection of BM cells, particularly MSCs, has repeatedly been shown to improve renal function in ATN, whether induced by toxins (cisplatin and glycerol) or I/R [reviewed in 23, 27]. With the role of actual engraftment of BM cells as tubular cells thought to be minimal or absent, MSCs may exert their beneficial effects through their antiapoptotic, mitogenic, immunomodulatory and angiogenic properties, or through the contribution of the BM cells to endothelial 
cell replacement in the peritubular capillaries. Research is now focusing on the nature of the mediators involved in these properties, and the mechanisms governing the homing of MSCs to the kidney [23]. Imberti et al. [30] confirmed the importance of paracrine mechanisms using co-culture of MSCs with tubular cells in a Transwell ${ }^{\circledR}$ culture excluding contact between the two cell types, which led to less cisplatin-induced tubular cell death. MSCs have been shown to produce vascular endothelial growth factor, basic fibroblast growth factor, monocyte chemoattractant protein-1, hepatocyte growth factor, and insulin-like growth factor, as well as immunomodulators TGF- $\beta$ and PGE $_{2}[23,31]$. In a recent study, administration of conditioned medium from cultured stromal cells provided the same renoprotective effects as injection of MSCs, suggesting that systemic administration of the beneficial mediators may be just as good as MSC injection, and safer [31]. It is a concern that there have been a few observations of adipogenesis associated with fibrosis and osteogenesis after injection of MSCs [reviewed in 23].

MSC homing to the kidney has been linked to interactions between molecules upregulated in the injured kidney (SDF-1, hyaluronic acid and PDGF) and ligands expressed on MSCs (respectively, CXCR4, CD44 and PDGF-R) [reviewed in 23].

Similar beneficial effects on renal function may be induced by mobilizing BM cells from the patient's own BM by administration of growth factors (GF) such as granulocyte colony-forming factor, granulocyte/monocyte colony-forming factor, monocyte colony-forming factor, and stem cell factor. Most of the studies suggest that administration of GF can lead to improvement of renal function after I/R or toxic injury [32-35], but not all [36]. Possible explanations for improved renal function include increased numbers of BM-derived tubular cells, a decrease in neutrophilic infiltrate, or increased cell proliferation and decreased apoptosis in kidneys of GF-treated mice.

In summary, most but not all authors agree that a small proportion of tubular cells (at most a few percent) are BM-derived after renal injury. The role these BM-derived tubular cells play in improved renal function is probably insignificant, with intrinsic renal cells, either stem cells or differentiated, more likely to play the predominant role in regeneration. However, administration of BM cells or mobilization of BM cells using GF may be used to protect against renal injury. This may be due to paracrine/immunomodulatory effects or endothelial regeneration. In addition, there may be a therapeutic role for BM-derived cells engineered to replace a defective gene, due to a local strong positive selective pressure. MSCs have emerged as the most promising candidate for stem cell therapy, and appear safe, such that phase I clinical trials of MSC injection for the treatment of acute kidney injury are scheduled to begin shortly [reviewed in 23].

\section{Mesangial Cells}

Mesangial cells are modified smooth muscle cells in the glomerular tuft, and provide structural support for the complex of glomerular capillaries. They may be injured by immune complex deposition, toxins and in diabetes. Although mesangial cells have regenerative potential, persistent mesangial damage can lead to glomerulosclerosis.

In cell culture, BM cells treated with PDGF-BB in the presence of collagen IV convert to cells with many mesangial characteristics [37].

In rodent models of BM transplantation, there is also support for partial BM derivation of mesangial cells, whether glomeruli are injured or not [38-42]. In models where mesangial damage has been induced, infusion of BM cells may be associated with improved function, which has been attributed to mesangial and endothelial regeneration [42] or, in the case of MSCs, paracrine mechanisms [43]. Conversely, a deleterious mesangial phenotype responsible for mesangial sclerosis, such as in Os/or $\mathrm{db} / \mathrm{db}$ mice, can be induced by transplanting wild-type mice with transgenic mouse BM $[40,44]$. Some studies have further illustrated functionality of the BM-derived mesangial cells by harvesting the BM-derived mesangial cells, growing them in culture, and showing angiotensinII induced contraction in vitro, a typical mesangial function $[40,41,44]$.

These studies support partial derivation of mesangial cells from the BM after injury, and a possible role in healing of glomerulonephritis.

\section{Podocytes}

Podocytes are epithelial cells with complex interdigitating foot processes which create the slit diaphragm, and contribute to the synthesis of the glomerular basement membrane. Both the slit diaphragm and the glomerular basement membrane are implicated in creating a filtration barrier between blood and urine.

Initial studies identified rare BM-derived cells at the periphery of the glomerular tuft, in the location of podocytes [45]. Two recent studies have suggested integration of BM-derived cells as functional podocytes, with pro- 
duction of matrix protein. These studies involved the use of a mouse model of Alport's disease, in which the animals suffer from defective synthesis of the $\alpha 3$ chain of collagen type IV, with glomerular basement membrane abnormalities and progression to glomerulosclerosis and renal failure. Using whole $\mathrm{BM}$ transplantation from wild-type animals, both Prodromidi et al. [46] and Sugimoto et al. [47] showed the presence of BM-derived podocytes and mesangial cells, accompanied by re-expression of the defective collagen chains, and improved renal histology and function $[46,47]$. Although the BMderived cells were not numerous, their presence was sufficient to re-establish synthesis of the defective collagen chain. However, the improvement in renal function was substantial raising the possibility that there may be mechanisms involved other than replacement of podocytes. A similar experiment using MSCs only rather than whole BM also led to a reduction in interstitial fibrosis, but without engraftment of BM cells in the kidney, and with no beneficial effect on survival or renal function [48]. In this study, the positive effects were attributed to paracrine factors.

\section{Vascular Cells}

Endothelial cells are present in the glomerular capillaries, in large vessels and in the abundant network of peritubular capillaries. Endothelial cells are attractive candidates for progeny of BM-derived cells in view of their immediate contact with circulating cells, the existence of known circulating endothelial precursors, and the existence of a known endothelial precursor in the BM: the haemangioblast.

In a rat model of glomerulonephritis, where glomerular endothelial cells are injured, culture-modified BM mononuclear cells injected into the renal artery boosted renal regeneration [49]. This was attributed both to incorporation of BM-derived cells into the endothelial lining and to production of angiogenic factors by the injected cells. Similarly, following acute tubular necrosis, the peritubular capillaries are damaged. The return of blood flow, which depends on endothelial cell integrity, is essential for renal recovery. Duffield et al. [26] contend that $\mathrm{BM}$ cells boost renal function after I/R by participating in endothelial cell regeneration.

Li et al. [50] observed BM-derived $\mathrm{vWF}+$ and CD31+ endothelial cells in a mouse model of adriamycin-induced nephrosis with subsequent renal fibrosis. This evidence points to an important role for BM-derived cells in vascular regeneration after injury.

Stem Cells and Renal Regeneration

\section{Interstitial Cells}

The kidney contains a complex population of interstitial cells serving several functions, such as providing a scaffold for renal structure and producing several hormonal substances such as erythropoietin. It may even contain a population of adult native renal stem cells which play a role in renal regeneration [reviewed in 9,27].

There is also evidence that BM-derived cells could be a source for up to $30 \%$ of $\alpha$-SMA-positive interstitial myofibroblasts [50-53], which have been incriminated in the production of extracellular matrix in renal fibrosis. If the BM is indeed a source for such cells, the use of BM cell injections for the treatment of renal failure would run the risk of enhancing fibrosis.

There is crucial disagreement on the issue of functionality of these cells. Do the BM-derived cells actively participate in extracellular matrix synthesis? Roufosse et al. [51] in a mouse model of unilateral ureteric obstruction, detected BM-derived $\alpha$-SMA-positive cells. Using two reporter molecules under the control of the promoter and enhancer elements of the collagen I $\alpha 2$ chain gene, we did not however observe any functional BM-derived fibroblasts or myofibroblasts producing collagen I. On the other hand, Iwano et al. [53] in a mouse model of unilateral ureteric obstruction, and Broekema et al. [52] in a rat model of unilateral I/R injury, demonstrated double immunostaining positivity of $\alpha$-SMA-positive interstitial cells with pro-collagen I protein.

Resolving these issues is important: BM-derived interstitial cells could be playing a regenerative or pro-fibrotic role or even both depending on the conditions under which they differentiate.

\section{Conclusion}

The theoretical background justifying the pursuit of the potential of BM cells to participate in renal regeneration has been laid. Stem cells, both embryonic and from the adult $\mathrm{BM}$, in the right conditions, can express renal markers in vitro and give rise to renal cells in vivo.

In addition, injection of stem cells into the kidney or the bloodstream can lead to an improvement of renal function, although this does not always seem to be mediated by transdifferentiation into renal cells. Current views favour a predominant role for the delivery of a cocktail of angiogenic and immunomodulatory mediators as the main means by which BM cells enhance epithelial and endothelial cell survival. As far as engraftment of BM cells as renal parenchymal cells is concerned, proving

Nephron Exp Nephrol 2008;109:e39-e45 
functionality of the engrafted BM-derived cells is crucial in order to assign to them a role in improved renal function, rather than relying on morphological observations alone.
Whether stem cell injections will ever be used for the treatment of renal failure is at this stage still unknown. There is certainly some hope to be found in the numerous animal models that have been developed and analysed over the last few years.

\section{References}

1 Lin F: Stem cells in kidney regeneration following acute renal injury. Pediatr Res 2006; 59:74R-78R.

-2 Yamamoto M, Cui L, Johkura K, Asanuma K, Okouchi Y, Ogiwara N, Sasaki K: Branching ducts similar to mesonephric ducts or ureteric buds in teratomas originating from mouse embryonic stem cells. Am J Physiol Renal Physiol 2006;290:F52-F60.

-3 Steenhard BM, Isom KS, Cazcarro P, Dunmore JH, Godwin AR, St John PL, Abrahamson DR: Integration of embryonic stem cells in metanephric kidney organ culture. J Am Soc Nephrol 2005; 16:1623-1631.

4 Kobayashi T, Tanaka H, Kuwana H, Inoshita S, Teraoka H, Sasaki S, Terada Y: Wnt4transformed mouse embryonic stem cells differentiate into renal tubular cells. Biochem Biophys Res Commun 2005;336:585595.

5 Kim D, Dressler GR: Nephrogenic factors promote differentiation of mouse embryonic stem cells into renal epithelia. J Am Soc Nephrol 2005;16:3527-3534.

-6 Vigneau C, Polgar K, Striker G, Elliott J, Hyink D, Weber O, Fehling HJ, Keller G, Burrow C, Wilson P: Mouse embryonic stem cell-derived embryoid bodies generate progenitors that integrate long term into renal proximal tubules in vivo. J Am Soc Nephrol 2007; 18:1709-1720.

7 Bruce SJ, Rea RW, Steptoe AL, Busslinger M, Bertram JF, Perkins AC: In vitro differentiation of murine embryonic stem cells toward a renal lineage. Differentiation 2007;75:337349.

-8 Schuldiner M, Yanuka O, Itskovitz-Eldor J, Melton DA, Benvenisty N: Effects of eight growth factors on the differentiation of cells derived from human embryonic stem cells. Proc Natl Acad Sci USA 2000;97:1130711312

$\checkmark 9$ Little $\mathrm{MH}$ : Regrow or repair: potential regenerative therapies for the kidney. J Am Soc Nephrol 2006;17:2390-2401.

-10 Dekel B, Burakova T, Arditti FD, Reich-Zeliger S, Milstein O, Aviel-Ronen S, Rechavi G, Friedman N, Kaminski N, Passwell JH, Reisner Y: Human and porcine early kidney precursors as a new source for transplantation. Nat Med 2003;9:53-60.
11 Lazzeri E, Crescioli C, Ronconi E, Mazzinghi B, Sagrinati C, Netti GS, Angelotti ML, Parente E, Ballerini L, Cosmi L, Maggi L, Gesualdo L, Rotondi M, Annunziato F, Maggi E, Lasagni L, Serio M, Romagnani S, Vannelli GB, Romagnani P: Regenerative potential of embryonic renal multipotent progenitors in acute renal failure. J Am Soc Nephrol 2007; 18:3128-3138.

12 Kitamura S, Yamasaki Y, Kinomura M, Sugaya T, Sugiyama H, Maeshima Y, Makino $\mathrm{H}$ : Establishment and characterization of renal progenitor like cells from s3 segment of nephron in rat adult kidney. FASEB J 2005; 19:1789-1797.

13 Fujigaki Y, Goto T, Sakakima M, Fukasawa H, Miyaji T, Yamamoto T, Hishida A: Kinetics and characterization of initially regenerating proximal tubules in $\mathrm{s} 3$ segment in response to various degrees of acute tubular injury. Nephrol Dial Transplant 2006;21:4150

14 Gupta S, Verfaillie C, Chmielewski D, Kren S, Eidman K, Connaire J, Heremans Y, Lund T, Blackstad M, Jiang Y, Luttun A, Rosenberg ME: Isolation and characterization of kidney-derived stem cells. J Am Soc Nephrol 2006;17:3028-3040.

15 Maeshima A, Yamashita S, Nojima Y: Identification of renal progenitor-like tubular cells that participate in the regeneration processes of the kidney. J Am Soc Nephrol 2003; 14 : 3138-3146.

16 Maeshima A, Sakurai H, Nigam SK: Adult kidney tubular cell population showing phenotypic plasticity, tubulogenic capacity, and integration capability into developing kidney. J Am Soc Nephrol 2006;17:188-198.

17 Sagrinati C, Netti GS, Mazzinghi B, Lazzeri E, Liotta F, Frosali F, Ronconi E, Meini C, Gacci M, Squecco R, Carini M, Gesualdo L, Francini F, Maggi E, Annunziato F, Lasagni L, Serio M, Romagnani S, Romagnani P: Isolation and characterization of multipotent progenitor cells from the Bowman's capsule of adult human kidneys. J Am Soc Nephrol 2006;17:2443-2456.

18 Dekel B, Zangi L, Shezen E, Reich-Zeliger S, Eventov-Friedman S, Katchman H, JacobHirsch J, Amariglio N, Rechavi G, Margalit $\mathrm{R}$, Reisner Y: Isolation and characterization of nontubular sca-1+lin- multipotent stem/ progenitor cells from adult mouse kidney. J Am Soc Nephrol 2006;17:3300-3314.
19 Oliver JA, Maarouf O, Cheema FH, Martens TP, Al-Awqati Q: The renal papilla is a niche for adult kidney stem cells. J Clin Invest 2004;114:795-804.

20 Bussolati B, Bruno S, Grange C, Buttiglieri S, Deregibus MC, Cantino D, Camussi G: Isolation of renal progenitor cells from adult human kidney. Am J Pathol 2005;166:545555.

21 Vogetseder A, Picard N, Gaspert A, Walch M, Kaissling B, Le Hir M: The proliferation capacity of the renal proximal tubule involves the bulk of differentiated epithelial cells. Am J Physiol Cell Physiol 2008;294: C22-C28.

22 Witzgall R: Are renal proximal tubular epithelial cells constantly prepared for an emergency? Focus on 'the proliferation capacity of the renal proximal tubule involves the bulk of differentiated epithelial cells'. Am J Physiol Cell Physiol 2008;294:C1-C13.

$\checkmark 23$ Humphreys BD, Bonventre JV: Mesenchymal stem cells in acute kidney injury. Annu Rev Med 2008;59:311-325.

24 Vogetseder A, Palan T, Bacic D, Kaissling B, Le Hir M: Proximal tubular epithelial cells are generated by division of differentiated cells in the healthy kidney. Am J Physiol Cell Physiol 2007;292:C807-C813.

25 Lin F, Moran A, Igarashi P: Intrarenal cells, not bone marrow-derived cells, are the major source for regeneration in postischemic kidney. J Clin Invest 2005; 115:1756-1764.

26 Duffield JS, Park KM, Hsiao LL, Kelley VR, Scadden DT, Ichimura T, Bonventre JV: Restoration of tubular epithelial cells during repair of the postischemic kidney occurs independently of bone marrow-derived stem cells. J Clin Invest 2005;115:1743-1755.

27 Imai E, Iwatani H: The continuing story of renal repair with stem cells. J Am Soc Nephrol 2007;18:2423-2424.

28 Held PK, Al-Dhalimy M, Willenbring $\mathrm{H}$, Akkari Y, Jiang S, Torimaru Y, Olson S, Fleming WH, Finegold M, Grompe M: In vivo genetic selection of renal proximal tubules. Mol Ther 2006;13:49-58

29 Li L, Truong P, Igarashi P, Lin F: Renal and bone marrow cells fuse after renal ischemic injury. J Am Soc Nephrol 2007;18:30673077. 
30 Imberti B, Morigi M, Tomasoni S, Rota C, 38 Imasawa T, Utsunomiya Y, Kawamura T, Corna D, Longaretti L, Rottoli D, Valsecchi F, Benigni A, Wang J, Abbate M, Zoja C, Remuzzi G: Insulin-like growth factor-1 sustains stem cell mediated renal repair. J Am Soc Nephrol 2007; 18:2921-2928.

-31 Bi B, Schmitt R, Israilova M, Nishio H, Cantley LG: Stromal cells protect against acute tubular injury via an endocrine effect. J Am Soc Nephrol 2007;18:2486-2496.

\$2 Fang TC, Alison MR, Cook HT, Jeffery R, Wright NA, Poulsom R: Proliferation of bone marrow-derived cells contributes to regeneration after folic acid-induced acute tubular injury. J Am Soc Nephrol 2005;16: 1723-1732.

-33 Stokman G, Leemans JC, Claessen N, Weening JJ, Florquin S: Hematopoietic stem cell mobilization therapy accelerates recovery of renal function independent of stem cell contribution. J Am Soc Nephrol 2005;16:16841692.

34 Nishida M, Fujimoto S, Toiyama K, Sato H, Hamaoka K: Effect of hematopoietic cytokines on renal function in cisplatin-induced ARF in mice. Biochem Biophys Res Commun 2004;324:341-347.

-35 Iwasaki M, Adachi Y, Minamino K, Suzuki Y, Zhang Y, Okigaki M, Nakano K, Koike Y, Wang J, Mukaide H, Taketani S, Mori Y, Takahashi H, Iwasaka T, Ikehara S: Mobilization of bone marrow cells by G-CSF rescues mice from cisplatin-induced renal failure, and M-CSF enhances the effects of G-CSF. J Am Soc Nephrol 2005;16:658666.

-36 Togel F, Isaac J, Westenfelder C: Hematopoietic stem cell mobilization-associated granulocytosis severely worsens acute renal failure. J Am Soc Nephrol 2004;15:1261-1267.

-37 Suzuki A, Iwatani H, Ito T, Imai E, Okabe M, Nakamura H, Isaka Y, Yamato M, Hori M: Platelet-derived growth factor plays a critical role to convert bone marrow cells into glomerular mesangial-like cells. Kidney Int 2004;65:15-24.
Zhong Y, Nagasawa R, Okabe M, Maruyama N, Hosoya T, Ohno T: The potential of bone marrow-derived cells to differentiate to glomerular mesangial cells. J Am Soc Nephrol 2001;12:1401-1409.

39 Ito T, Suzuki A, Imai E, Okabe M, Hori M: Bone marrow is a reservoir of repopulating mesangial cells during glomerular remodeling. J Am Soc Nephrol 2001;12:2625-2635.

40 Cornacchia F, Fornoni A, Plati AR, Thomas A, Wang Y, Inverardi L, Striker LJ, Striker GE: Glomerulosclerosis is transmitted by bone marrow-derived mesangial cell progenitors. J Clin Invest 2001;108:1649-1656.

41 Masuya M, Drake CJ, Fleming PA, Reilly CM, Zeng H, Hill WD, Martin-Studdard A, Hess DC, Ogawa M: Hematopoietic origin of glomerular mesangial cells. Blood 2003;101: 2215-2218.

42 Li B, Morioka T, Uchiyama M, Oite T: Bone marrow cell infusion ameliorates progressive glomerulosclerosis in an experimental rat model. Kidney Int 2006;69:323-330.

43 Kunter U, Rong S, Djuric Z, Boor P, MullerNewen G, Yu D, Floege J: Transplanted mesenchymal stem cells accelerate glomerular healing in experimental glomerulonephritis. J Am Soc Nephrol 2006; 17:2202-2212.

44 Zheng F, Cornacchia F, Schulman I, Banerjee A, Cheng QL, Potier M, Plati AR, Berho M, Elliot SJ, Li J, Fornoni A, Zang YJ, Zisman A, Striker LJ, Striker GE: Development of albuminuria and glomerular lesions in normoglycemic B6 recipients of $\mathrm{db} / \mathrm{db}$ mice bone marrow: The role of mesangial cell progenitors. Diabetes 2004;53:2420-2427.

45 Poulsom R, Forbes SJ, Hodivala-Dilke K, Ryan E, Wyles S, Navaratnarasah S, Jeffery R, Hunt T, Alison M, Cook T, Pusey C, Wright NA: Bone marrow contributes to renal parenchymal turnover and regeneration. J Pathol 2001;195:229-235.

46 Prodromidi EI, Poulsom R, Jeffery R, Roufosse CA, Pollard PJ, Pusey CD, Cook HT: Bone marrow-derived cells contribute to podocyte regeneration and amelioration of renal disease in a mouse model of Alport syndrome. Stem Cells 2006;24:2448-2455.
47 Sugimoto H, Mundel TM, Sund M, Xie L, Cosgrove D, Kalluri R: Bone-marrow-derived stem cells repair basement membrane collagen defects and reverse genetic kidney disease. Proc Natl Acad Sci USA 2006;103: 7321-7326.

48 Ninichuk V, Gross O, Segerer S, Hoffmann R, Radomska E, Buchstaller A, Huss R, Akis N, Schlondorff D, Anders HJ: Multipotent mesenchymal stem cells reduce interstitial fibrosis but do not delay progression of chronic kidney disease in COL4A3-deficient mice. Kidney Int 2006;70:121-129.

49 Uchimura H, Marumo T, Takase O, Kawachi H, Shimizu F, Hayashi M, Saruta T, Hishikawa K, Fujita T: Intrarenal injection of bone marrow-derived angiogenic cells reduces endothelial injury and mesangial cell activation in experimental glomerulonephritis. J Am Soc Nephrol 2005; 16:997-1004.

50 Li J, Deane JA, Campanale NV, Bertram JF, Ricardo SD: The contribution of bone marrow-derived cells to the development of renal interstitial fibrosis. Stem Cells 2007;25:697706.

51 Roufosse C, Bou-Gharios G, Prodromidi E, Alexakis C, Jeffery R, Khan S, Otto WR, Alter J, Poulsom R, Cook HT: Bone marrowderived cells do not contribute significantly to collagen I synthesis in a murine model of renal fibrosis. J Am Soc Nephrol 2006;17: 775-782.

52 Broekema M, Harmsen MC, van Luyn MJ, Koerts JA, Petersen AH, van Kooten TG, van Goor H, Navis G, Popa ER: Bone marrowderived myofibroblasts contribute to the renal interstitial myofibroblast population and produce procollagen I after ischemia/reperfusion in rats. J Am Soc Nephrol 2007;18: $165-175$.

53 Iwano M, Plieth D, Danoff TM, Xue C, Okada H, Neilson EG: Evidence that fibroblasts derive from epithelium during tissue fibrosis. J Clin Invest 2002;110:341-350. 